\title{
EFFECT OF N FERTILIZER FORMS AND SOIL MOISTURE LEVELS ON THE N GASEOUS LOSSES
}

\author{
*NótÁs, E. ${ }^{1}$ - Molnár, E. ${ }^{1}$ - Ruzsa, D. ${ }^{1}$ - Csoma, Z. ${ }^{2}$ - Debreczeni, K. ${ }^{3}$ - Heltai, Gy. ${ }^{1}$ \\ ${ }^{1}$ Szent István University, Faculty of Agricultural and Environmental Sciences, Department of \\ Chemistry and Biochemistry, \\ H-2103 Gödöllö, Páter Károly u. 1. \\ (phone: +36-28-522-000/1668; fax: +36-28-410-804)
}

${ }^{2}$ Ferenc Rákóczi II. Transcarpathian Hungarian Institute, Department of Biology and Chemistry, 90202 Beregovo, Kossuth tér 6, Ukraine

${ }^{3}$ Pannonia University, Georgikon Faculty of Agricultural Sciences, H-8360 Keszthely, Deák F. u. 16.

\author{
*Corresponding author \\ e-mail:notas.erika@mkk.szie.hu
}

(Received 22 ${ }^{\text {nd }}$ Apr 2014 ; accepted $22^{\text {nd }}$ July 2014 )

\begin{abstract}
In a pot experiment using brown forest soil with clay eluviation (40 kg soil/pot) from Keszthely the gaseous losses of nitrogen (total $\mathrm{N}, \mathrm{N}_{2}, \mathrm{~N}_{2} \mathrm{O} \mathrm{NO} \mathrm{NO}_{2}$ ) caused by denitrification were tested. Gas-collecting traps were placed at a depth of $20 \mathrm{~cm}$ in the soil. At the same fertilizer $\mathrm{N}$ input $\left(6250 \mathrm{mgN} /\right.$ pot, $150 \mathrm{mg} \mathrm{N} / \mathrm{kg}$ soil), the effects of two fertilizer forms $\left(\mathrm{KNO}_{3}, \mathrm{NH}_{4} \mathrm{Cl}\right)$ and two soil moisture levels (field water holding capacity, $\mathrm{WHC}=65 \%$ and $100 \%$ ) were evaluated to the gaseous losses of nitrogen with and without sowing of maize hybrids (two Stira and two Mv 355/pot) as test plants. The composition of the N-containing gases was determined by gas chromatography. From the soilatmosphere the gas samples were taken 8 times, the sampling times were on the 2, 16, 30, 54, 68, 82, 110, 138 -th days of the experiment. Statistical evaluation of the results was performed by analysis of variance. The $\mathrm{N}$ gaseous loss in the planted pots was the $12 \%$ of the applied fertilizer dose, while in unplanted pots it was nearly the double of it (22\%) Consequently, there was a $50 \%$ decrease in the denitrification gaseous losses of fertilizer $\mathrm{N}$ due to plant $\mathrm{N}$ uptake. The $\mathrm{N}$-gaseous loss was significantly higher in cases of $\mathrm{KNO}_{3}$ applications and at the $\mathrm{WHC}=100 \%$ soil moisture than in $\mathrm{NH}_{4} \mathrm{Cl}$ treatments and at the $\mathrm{WHC}=$ $65 \%$, probably due to more intensive denitrification. In the unplanted pots the amount of $\mathrm{N}_{2}$ and $\mathrm{N}_{2} \mathrm{O}$ increased the most (by $95 \%$ and by $70 \%$ ) compared with planted pots. It can be concluded that the improperly applied fertilizer causes significant GHG emissions in the absence of plants.
\end{abstract}

Keywords: $N$-gaseous losses, nitrous-oxide, GHG emission, fertilizer treatment, soil moisture

\section{Introduction}

The relative contributions of the three main greenhouse gases (GHG): $\mathrm{CO}_{2}, \mathrm{CH}_{4}$ and $\mathrm{N}_{2} \mathrm{O}$ to overall global radiative forcing are $63.5 \%, 18.1 \%$ and $6.2 \%$, respectively. Soils are one of the major sources of GHG contribution both to anthropogenic emissions due to land use change and agricultural management (up to $22.5 \%$ of all anthropogenic sources) (Blagodatsky and Smith, 2012). Yienger and Levy (1995) estimate for annual above-canopy emissions is $5.5 \mathrm{Tg} \mathrm{N}\left(\mathrm{NO}_{\mathrm{x}}\right)$ with a range of 3.3-7.7 $\mathrm{Tg} \mathrm{N}$. Globally the strongest emitters are agriculture, grasslands, and tropical rain forests, accounting for $41 \%, 35 \%$ and $16 \%$ of the annual budget, respectively."Pulsing" (the emissions burst following the wetting of a dry soil) contributes $1,3 \mathrm{Tg} \mathrm{N}$ annually. In temperate regions, agriculture dominates emission, and in tropical regions, grassland dominates. By the 
year 2025, the increasing use of nitrogen fertilizer may raise total annual emissions to 6.9 $\mathrm{Tg} \mathrm{N}$ with agriculture accounting for more than $50 \%$ of the global source. The agriculture is a significant contributor to the increasing $\mathrm{N}_{2} \mathrm{O}$ concentration of air (Delmas et al., 1997; Hellebrand et al.,2003; Ruser et al., 2006). The agriculture is estimated to contribute more than two-thirds of total anthropogenic $\mathrm{N}_{2} \mathrm{O}$ emissions (Pattey et al., 2007). The agricultural soils emit $3.3 \mathrm{Mt} \mathrm{N}_{2} \mathrm{O}$ per year (Mosier et al.,1998). As the global warming potential of $\mathrm{N}_{2} \mathrm{O}$ is 298 times as strong as that of $\mathrm{CO}_{2}$, $\mathrm{N}_{2} \mathrm{O}$ emissions from soils thereby exert an important impact on the environment. Soil microbial processes, nitrification and denitrification contribute significantly to the agricultural $\mathrm{N}_{2} \mathrm{O}$ emission (Stange and Döhling, 2005). N-gaseous emissions from agricultural soils, speciation of predicted gas $\mathrm{N}$ flux into $\mathrm{N}_{2} \mathrm{O}$ and $\mathrm{N}_{2}$ depend on the $\mathrm{N}$ fertilizer dose and type, the soil type and $\mathrm{pH}$, the soil moisture, the oxygen supply and the $\mathrm{C} / \mathrm{N}$ ratio of the soil, application practice, the vegetation and the temperature (Ma et al., 2007; Chu et al., 2007, Gu et al, 2009). Field response to fertilizaton is variable; some plots have enhanced emissions for prolonged periods, whereas others have sharper initial increases that decay over time. In general, however a positive linear correlation seems to be between fertilizer use and emission, and over the course of a growing season, total $\mathrm{NO}_{\mathrm{x}}$ emissions change between 1-10\% of added nitrogen fertilizer (Williams et al., 1992; Shepard et al., 1991, Cardenas et al., 1993). The exact fertilizer form which is more stimulatory depends on the site, although evidence suggests that a mixed form, such as $\mathrm{NH}_{4} \mathrm{NO}_{3}$, generates strongest emission (Sanhueza, 1992). In a pot experiment the total $\mathrm{N}$ gaseous losses were higher at $\mathrm{KNO}_{3}$ treatment than $\mathrm{NH}_{4} \mathrm{Cl}$ treatment in brown forest soil with clay eluviation (Debreczeni et al. 1998). The $\mathrm{N}_{2} \mathrm{O}$ emissions from $\mathrm{NH}_{4}{ }^{+}-\mathrm{N}$ fertilizer were higher than from urea and $\mathrm{NO}_{3}{ }^{-} \mathrm{N}$ fertilizers in coarse- textured soils (Gu et al, 2009). Kramer et al.(1999) studied greenhouse gas emissions of Dutch agricultural crop production by using a life cycle approach. It was determined that the emissions of $\mathrm{N}_{2} \mathrm{O}$ are mainly caused by the production and application of synthetic nitrogen fertilizer. The use of other nitrogen sources manure, compost or limiting the use of synthetic nitrogen could positively influence the emissions of $\mathrm{N}_{2} \mathrm{O}$. In contrast, Jones et al. (2005) found that during growing season the cumulative total $\mathrm{N}_{2} \mathrm{O}$ flux from manure treatments was 25 times larger than that from mineral fertilizers. Large inputs of manure $\mathrm{N}$ have a potential to contribute a very high $\mathrm{N}_{2} \mathrm{O}$ emissions, particularly in wet soil conditions. The ratio of $\mathrm{NO}_{\mathrm{x}}$ gases depends on the soil moisture. In an experiment testing the tropical rain forest ecosystem during dry periods the NO-N: $\mathrm{N}_{2} \mathrm{O}-\mathrm{N}$ ratio was as high as $60: 1$, whereas for wetter periods it decreased to $<7: 1$. (Butterbach et al, 2004). In Hungary, where the proportion of agricultural area to the total area of the country is quite high $(63 \%)$ it is essential to investigate agricultural contribution to greenhouse gas emission.

\section{Material and methods}

Brown forest soil with clay eluviation from Keszthely $\left(\mathrm{pH}_{\mathrm{KCl}}=7.7, \mathrm{C}=1.1 \%, \mathrm{NO}_{3}-\mathrm{N}\right.$ $=17.5 \mathrm{mg} \mathrm{kg}^{-1}, \mathrm{NH}_{4}-\mathrm{N}=12 \mathrm{mg} \mathrm{kg}^{-1}$, humus $\left.=1.9 \%\right)$ was filled in large plastic pots (40 $\mathrm{kg}$ soil/pot). $\mathrm{N}$ fertilizers $\left(\mathrm{KNO}_{3}, \mathrm{NH}_{4} \mathrm{Cl}\right)$ were applied at a high rate of approx. $150 \mathrm{mg}$ $\mathrm{N} \mathrm{kg}^{-1}$ soil (6 $250 \mathrm{mg} \mathrm{N} /$ pot) to trace the precise transformation processes of $\mathrm{N}, \mathrm{P}$ fertilizer in all treated soils, and $\mathrm{K}$ fertilizer in $\mathrm{NH}_{4} \mathrm{Cl}$ treatments was also used $(\mathrm{N}: \mathrm{P}: \mathrm{K}=$ 1:1:3.35). All experiments were carried out at two soil moisture levels (field water holding capacity, $\mathrm{WHC}=65 \%$ and $100 \%$ ) with and without sowing of maize as test 
plants (two Stira and two Mv355 plants/pot) (Table1). For statistical calculations, results of maize hybrids were taken as replicates. The plants were grown until full ripening. Maize (Zea mays L.) was sown in 48 pots, and 32 pots were left without plant.

Table 1. Setting up of the experiment

\begin{tabular}{|c|c|c|c|c|c|c|c|c|c|c|c|c|c|}
\hline \multirow{3}{*}{$\begin{array}{c}\text { Maize hybrid } \\
\text { Stira } \\
\end{array}$} & \multirow{4}{*}{$\begin{array}{c}\text { Treatment } \\
\text { WHC \% }\end{array}$} & \multicolumn{6}{|c|}{ With maize } & \multicolumn{6}{|c|}{ Without maize } \\
\hline & & \multicolumn{2}{|c|}{ Control } & \multicolumn{2}{|c|}{$\mathrm{KNO}_{3}+\mathrm{P}$} & \multicolumn{2}{|c|}{$\mathrm{NH}_{4} \mathrm{Cl}+\mathrm{PK}$} & \multicolumn{2}{|c|}{ Control } & \multicolumn{2}{|c|}{$\mathrm{KNO}_{3}+\mathrm{P}$} & \multicolumn{2}{|c|}{$\mathrm{NH}_{4} \mathrm{Cl}+\mathrm{PK}$} \\
\hline & & 100 & 65 & 100 & 65 & 100 & 65 & 100 & 65 & 100 & 65 & 100 & 65 \\
\hline MV 355 & & 100 & 65 & 100 & 65 & 100 & 65 & 100 & 65 & 100 & 65 & 100 & 63 \\
\hline
\end{tabular}

All treatments were replicated four times. Gas-collecting traps of $1800 \mathrm{~cm}^{3}$ capacity with silicon pipe outlets were placed at a depth of $20 \mathrm{~cm}$ in the soil. The traps collected the $\mathrm{N}$ gaseous losses $\left(\mathrm{NO}, \mathrm{NO}_{2}, \mathrm{~N}_{2} \mathrm{O}, \mathrm{N}_{2}\right.$ ) released during the denitrification process. Gas samples were taken 8 times by syringe $\left(5 \mathrm{~cm}^{3}\right)$ in 3 replicates from the soil atmosphere. For soil atmosphere analysis the composition of the $\mathrm{N}$-containing gases $\left(\mathrm{N}_{2}, \mathrm{NO}, \mathrm{NO}_{2}, \mathrm{~N}_{2} \mathrm{O}\right)$ was determined by a Carlo Erba 2350 type gas chromatograph. From these data the total gaseous $\mathrm{N}$ losses were calculated $(\mathrm{mg} \mathrm{N} /$ pot or mg N/1800 $\mathrm{cm}^{3}$ ) for each sampling point. At the end of the experiments the cumulative gaseous $\mathrm{N}$ losses and $\mathrm{N}_{2} \mathrm{O}-\mathrm{N}$ losses were also calculated by the difference method ( $\mathrm{N}$ content difference between treated and control gas samples) and by the calculations of the relative \% gaseous $\mathrm{N}$ losses. Results were analyzed by the means of analysis of variance (MANOVA). The statistical analyses were performed with a Microsoft Excel Macro (Aydinalp et al., 2008; Vágó et al., 2008)

\section{Results and discussion}

The total $\mathrm{N}$ and total $\mathrm{N}_{2} \mathrm{O}$ gaseous losses were found to depend significantly $\left(\mathrm{LSD}_{5 \%}=16,7\right.$ and 5,1$)$ on the presence or absence of the plants (Table 3). In control samples in the planted pots the total $\mathrm{N}$ gaseous losses were 1,4 times higher (at $65 \%$ and $100 \% \mathrm{WHC}$ ), the $\mathrm{N}_{2} \mathrm{O}$ gaseous losses were 1,6 times (at $65 \% \mathrm{WHC}$ ) and 1,9 times (at $100 \% \mathrm{WHC}$ ) higher than in the unplanted pots (Table 2). Similar results were obtained by Heltai et al. (2013) in a pot experiment in control samples. In contrast to the control, in the unplanted pots treated with fertilizer the total $\mathrm{N}$ and $\mathrm{N}_{2} \mathrm{O}$ gaseous losses were higher (1,4-1,7 times) than in the planted pots. Calculated by difference method the total $\mathrm{N}$ gaseous losses were higher in the unplanted pots by $78-84 \%$ at $\mathrm{KNO}_{3}$ treatment and by $71-73 \%$ at $\mathrm{NH}_{4} \mathrm{Cl}$ treatment while the total $\mathrm{N}_{2} \mathrm{O}$ gaseous losses were higher by $67-$ $72 \%$ and by $62-63 \%$ compared with planted pots.

The total $\mathrm{N}$ and total $\mathrm{N}_{2} \mathrm{O}$ gaseous losses were significantly higher in the $\mathrm{N}$-fertilizer treatments than in control samples (Table 3: $\mathrm{LSD}_{5 \%}=20,5$ and 6,3). The difference of total $\mathrm{N}$ gaseous losses was 7 times higher in $\mathrm{KNO}_{3}$ and $\mathrm{NH}_{4} \mathrm{Cl}$ treatment in the planted pots while in the unplanted pots it was 16-17 times higher than in the controls (Table 2). The difference of $\mathrm{N}_{2} \mathrm{O}$ gaseous losses was 5-6 times higher in the planted pots and 1415 times higher in the unplanted pots in fertilized pots than in the controls. The total $\mathrm{N}$ and total $\mathrm{N}_{2} \mathrm{O}$ gaseous losses were more intensive in case of $\mathrm{KNO}_{3}$ treatment than in $\mathrm{NH}_{4} \mathrm{Cl}$ treatment (Table 3: $\mathrm{LSD}_{5 \%}=20,5$ and 6,3). 
Table 2. Total $\mathrm{N}$ and total $\mathrm{N}_{2} \mathrm{O}$ gaseous losses $\left(\mathrm{Nmg} / 1800 \mathrm{~cm}^{3)}(+\right.$ with plant, - without plant)

\begin{tabular}{|c|c|c|c|c|}
\hline Treatment & Maize & $\underset{\%}{\text { WHC }}$ & $\sum \mathbf{N}$ & $\sum \mathbf{N}_{2} \mathbf{O}$ \\
\hline \multirow{2}{*}{ Control } & \multirow{2}{*}{+} & 100 & 131,5 & 20 \\
\hline & & 65 & 119,5 & 16,5 \\
\hline \multirow{2}{*}{$\mathrm{KNO}_{3}$} & \multirow{2}{*}{+} & 100 & 921 & 107 \\
\hline & & 65 & 868,5 & 96 \\
\hline \multirow{2}{*}{$\mathrm{NH}_{4} \mathrm{Cl}$} & \multirow[b]{2}{*}{+} & 100 & 907,5 & 102 \\
\hline & & 65 & 868,5 & 93,5 \\
\hline \multirow{2}{*}{ Control } & \multirow[b]{2}{*}{-} & 100 & 91,5 & 10,5 \\
\hline & & 65 & 85,5 & 10 \\
\hline \multirow{2}{*}{$\mathrm{KNO}_{3}$} & \multirow{2}{*}{ - } & 100 & 1494 & 156 \\
\hline & & 65 & 1461,5 & 146,5 \\
\hline \multirow{2}{*}{$\mathrm{NH}_{4} \mathrm{Cl}$} & \multirow{2}{*}{ - } & 100 & 1438 & 144,5 \\
\hline & & 65 & 1369 & 135 \\
\hline
\end{tabular}

Table 3. Analysis of variance of total $\mathrm{N}$ and total $\mathrm{N}_{2} \mathrm{O}$ gaseous losses according to plant presence, soil moisture and treatment ( $\mathrm{N}$ and $\mathrm{N}_{2} \mathrm{O} \mathrm{mg} / 1800 \mathrm{~cm}^{3}$ )

\begin{tabular}{|c|c|c|}
\hline $\begin{array}{l}\text { Plant } \\
\text { presence }\end{array}$ & $\sum \mathbf{N}$ & $\sum \mathbf{N}_{\mathbf{2}} \mathbf{O}$ \\
\hline Maize + & 636 & 73 \\
\hline Maize - & 990 & 100 \\
\hline $\mathrm{LSD}_{5 \%}$ & $\mathbf{1 6 , 7}$ & $\mathbf{5 , 1}$ \\
\hline
\end{tabular}

\begin{tabular}{|c|c|c|}
\hline $\begin{array}{l}\text { Soil moisture } \\
\text { (WHC\%) }\end{array}$ & $\sum \mathbf{N}$ & $\sum_{\mathbf{2}} \mathbf{O}$ \\
\hline $100 \%$ & 831 & 90 \\
\hline $65 \%$ & 795 & 83 \\
\hline $\mathrm{LSD}_{5 \%}$ & $\mathbf{1 6 , 7}$ & $\mathbf{5 , 1}$ \\
\hline
\end{tabular}

\begin{tabular}{|c|c|c|}
\hline Treatment & $\sum \mathbf{N}$ & $\sum \mathbf{N}_{\mathbf{2}} \mathbf{O}$ \\
\hline Control & 107 & 14,3 \\
\hline $\mathrm{KNO}_{3}$ & 1186 & 126 \\
\hline $\mathrm{NH}_{4} \mathrm{Cl}$ & 1146 & 119 \\
\hline $\mathrm{LSD}_{5 \%}$ & $\mathbf{2 0 , 5}$ & $\mathbf{6 , 3}$ \\
\hline
\end{tabular}

The difference was significant in the unplanted pots only (Table 4: $\mathrm{LSD}_{5 \%}=29$ and 8,8 ). Similar results were obtained in other pot experiments using same soil samples from Keszthely by Debreczeni et al.(1995, 1998) and Nótás et al. (2003).

Table 4. Analysis of variance of total $\mathrm{N}$ and total $\mathrm{N}_{2} \mathrm{O}$ gaseous losses according to plant presence $x$ treatment, plant presence $x$ soil moisture and treatment $x$ soil moisture $\left(\mathrm{N}\right.$ and $\mathrm{N}_{2} \mathrm{O} \mathrm{mg} / 1800 \mathrm{~cm}^{3}$ )

\begin{tabular}{|c|c|c|c|}
\hline \multicolumn{2}{|l|}{$\begin{array}{l}\text { Plant } \\
\text { presence } \mathbf{X} \\
\text { Treatment }\end{array}$} & $\mathbf{\Sigma N}$ & $\begin{array}{c}\boldsymbol{\Sigma} \\
\mathbf{N}_{\mathbf{2}} \mathbf{O}\end{array}$ \\
\hline \multirow{2}{*}{$\begin{array}{c}\text { Maize } \\
+\end{array}$} & $\begin{array}{c}\text { Cont- } \\
\text { rol }\end{array}$ & 126 & 18,3 \\
\cline { 2 - 4 } & $\mathrm{KNO}_{3}$ & 895 & 102 \\
\cline { 2 - 4 } $\mathrm{NH}_{4} \mathrm{Cl}$ & 888 & 98 \\
\hline \multirow{2}{*}{$\begin{array}{c}\text { Maize } \\
-\end{array}$} & $\begin{array}{c}\text { Cont- } \\
\text { rol }\end{array}$ & 89 & 10,3 \\
\cline { 2 - 4 } & $\mathrm{KNO}_{3}$ & 1478 & 151 \\
\cline { 2 - 4 } $\mathrm{NH}_{4} \mathrm{Cl}$ & 1404 & 140 \\
\hline $\mathrm{LSD}_{5 \%}$ & & $\mathbf{2 9}$ & $\mathbf{8 , 8}$ \\
\hline
\end{tabular}

\begin{tabular}{|c|c|c|c|}
\hline \multicolumn{2}{|c|}{$\begin{array}{c}\text { Plant presence } \\
\text { X Soil moisture }\end{array}$} & $\sum N$ & $\mathbf{\Sigma N}_{\mathbf{2}} \mathbf{O}$ \\
\hline \multirow{2}{*}{$\begin{array}{c}\text { Maize } \\
+\end{array}$} & $100 \%$ & 653 & 76,3 \\
\cline { 2 - 4 } & $65 \%$ & 619 & 68,7 \\
\hline \multirow{2}{*}{$\begin{array}{c}\text { Maize } \\
-\end{array}$} & $100 \%$ & 1008 & 103,7 \\
\cline { 2 - 4 } & $65 \%$ & 972 & 97,2 \\
\hline \multicolumn{2}{|c|}{ LSD $_{5 \%}$} & $\mathbf{2 3 , 6}$ & $\mathbf{7 , 2}$ \\
\hline
\end{tabular}

\begin{tabular}{|c|c|c|c|}
\hline \multicolumn{2}{|c|}{$\begin{array}{c}\text { Treatment } \mathbf{X} \\
\text { Soil moisture }\end{array}$} & $\sum \mathbf{N}$ & $\begin{array}{c}\boldsymbol{\Sigma} \\
\mathbf{N}_{\mathbf{2}} \mathrm{O}\end{array}$ \\
\hline $\begin{array}{c}\text { Cont- } \\
\text { rol }\end{array}$ & $100 \%$ & 111,5 & 15 \\
\cline { 2 - 4 } & $65 \%$ & 102,5 & 13 \\
\hline \multirow{2}{*}{$\mathrm{KNO}_{3}$} & $100 \%$ & 1207 & 132 \\
\cline { 2 - 4 } & $65 \%$ & 1165 & 121 \\
\hline \multirow{2}{*}{$\mathrm{NH}_{4} \mathrm{Cl}$} & $100 \%$ & 1173 & 123 \\
\cline { 2 - 4 } & $65 \%$ & 1119 & 114 \\
\hline \multicolumn{2}{|c|}{$\mathrm{LSD}_{5 \%}$} & $\mathbf{2 9}$ & $\mathbf{8 , 8}$ \\
\hline
\end{tabular}


The total $\mathrm{N}$ and total $\mathrm{N}_{2} \mathrm{O}$ gaseous losses were higher at $100 \% \mathrm{WHC}$ than $65 \% \mathrm{WHC}$ (Table 3: $\mathrm{LSD}_{5 \%}=16,7$ and 5,1 ). This difference of total $\mathrm{N}$ loss was equally significant in the planted and unplanted pots (Table 4: $\mathrm{LSD}_{5 \%}=23,6$ ), but the total $\mathrm{N}_{2} \mathrm{O}$ gaseous loss was significantly higher only in the planted pots (Table 4: $\left.\mathrm{LSD}_{5 \%}=7,2\right)$. The effect of the soil moisture was significant in the fertilized samples only, in the control samples it was not (Table 4: $\operatorname{LSD}_{5 \%}=29$ and 8,8). The differences were dependant on the presence or absence of the plants in control samples $7-10 \%$ and $5-20 \%$, these are not significant; while in $\mathrm{KNO}_{3}$ treatment $2-6 \%$ and $7-12 \%$, in $\mathrm{NH}_{4} \mathrm{Cl}$ treatment $5 \%$ and 7 $9 \%$, these are significant.

Figure 1 and 2 (on the basis of Table 5) show the rate of total $\mathrm{N}$ gaseous losses increase in the planted pots (Fig. 1) and in the unplanted pots (Fig. 2). Results of maize hybrids were averaged.

Table 5. Total $N$ gaseous losses in the sampling time, $\sum N m g / 1800 \mathrm{~cm} 3$ (- unplanted pots)

\begin{tabular}{|c|c|c|c|c|c|c|c|c|c|c|}
\hline \multirow[t]{2}{*}{ Treatment } & \multirow{2}{*}{$\begin{array}{l}\text { Maize } \\
\text { hybrid }\end{array}$} & \multirow{2}{*}{$\begin{array}{c}\text { WHC } \\
\% \\
\end{array}$} & \multicolumn{8}{|c|}{ Sampling time (day) } \\
\hline & & & 2. & 16. & 30. & 54. & 68. & 82. & 110. & 138. \\
\hline \multirow{4}{*}{ Control } & \multirow{2}{*}{ Stira } & 100 & 47 & 70 & 96 & 126 & 127 & 130 & 123 & 122 \\
\hline & & 65 & 37 & 62 & 7 & 108 & 113 & 122 & 112 & 115 \\
\hline & \multirow{2}{*}{ Mv 355} & 100 & 48 & 71 & 91 & 126 & 124 & 133 & 121 & 116 \\
\hline & & 65 & 31 & 65 & 80 & 101 & 105 & 117 & 100 & 109 \\
\hline \multirow{4}{*}{$\mathrm{KNO}_{3}$} & \multirow{2}{*}{ Stira } & 100 & 150 & 344 & 480 & 616 & 719 & 931 & 918 & 876 \\
\hline & & 65 & 110 & 305 & 448 & 587 & 619 & 848 & 836 & 844 \\
\hline & \multirow{2}{*}{ Mv 355} & 100 & 124 & 365 & 504 & 615 & 743 & 911 & 903 & 863 \\
\hline & & 65 & 116 & 337 & 474 & 589 & 692 & 889 & 858 & 874 \\
\hline \multirow{4}{*}{$\mathrm{NH}_{4} \mathrm{Cl}$} & \multirow{2}{*}{ Stira } & 100 & 121 & 337 & 475 & 589 & 604 & 918 & 894 & 855 \\
\hline & & 65 & 107 & 297 & 426 & 546 & 587 & 846 & 827 & 844 \\
\hline & \multirow{2}{*}{ Mv 355} & 100 & 119 & 333 & 492 & 595 & 701 & 893 & 897 & 870 \\
\hline & & 65 & 102 & 303 & 475 & 579 & 624 & 850 & 839 & 891 \\
\hline \multirow{2}{*}{ Control } & \multirow[b]{2}{*}{ - } & 100 & 40 & 47 & 58 & 76 & 84 & 94 & 86 & 89 \\
\hline & & 65 & 38 & 40 & 52 & 78 & 75 & 89 & 73 & 82 \\
\hline \multirow{2}{*}{$\mathrm{KNO}_{3}$} & \multirow[b]{2}{*}{ - } & 100 & 108 & 345 & 651 & 911 & 971 & 1156 & 1494 & 1493 \\
\hline & & 65 & 101 & 304 & 614 & 829 & 895 & 1125 & 1343 & 1473 \\
\hline \multirow{2}{*}{$\mathrm{NH}_{4} \mathrm{Cl}$} & \multirow{2}{*}{ - } & 100 & 108 & 342 & 658 & 891 & 956 & 1114 & 1415 & 1461 \\
\hline & & 65 & 93 & 300 & 614 & 824 & 852 & 1096 & 1352 & 1386 \\
\hline
\end{tabular}

It can be established that the sampling time significantly influences the production rates of total $\mathrm{N}$ gaseous losses. The change of total $\mathrm{N}$ gaseous losses growth can be characterized by two peaks, in the planted pots (Fig.1) on the $16^{\text {th }}$ and $82^{\text {nd }}$ day of the experiment and in the unplanted pots (Fig.2) later, on the 30th and 110th day. This differerence was probably caused by the increase of microbiological activity due to the effect of root secretion in the planted pots. Similar results were obtained in other pot experiments using the same soil type from Keszthely Debreczeni et al.(1995). The minimum values were received on the $68^{\text {th }}$ day in the planted and unplanted pots equally. The $\mathrm{N}$ gaseous emission fluctuations may be caused by periodic changes of soil bacteria's microbiological activity, life cycle and temperature.

In our experiment with maize the total $\mathrm{N}$ gaseous losses changed between 749-789 $\mathrm{mgN} / 1800 \mathrm{~cm}^{3}$ in the planted pots and between $1304-1408 \mathrm{mgN} / 1800 \mathrm{~cm}^{3}$ in the unplanted pots (Fig. 3). The total $\mathrm{N}$ gaseous losses in the planted pots were $12-13 \%$ of 
the applied fertilizer $\mathrm{N}$ while in the pots without maize it was about twice as much, 21$22 \%$.

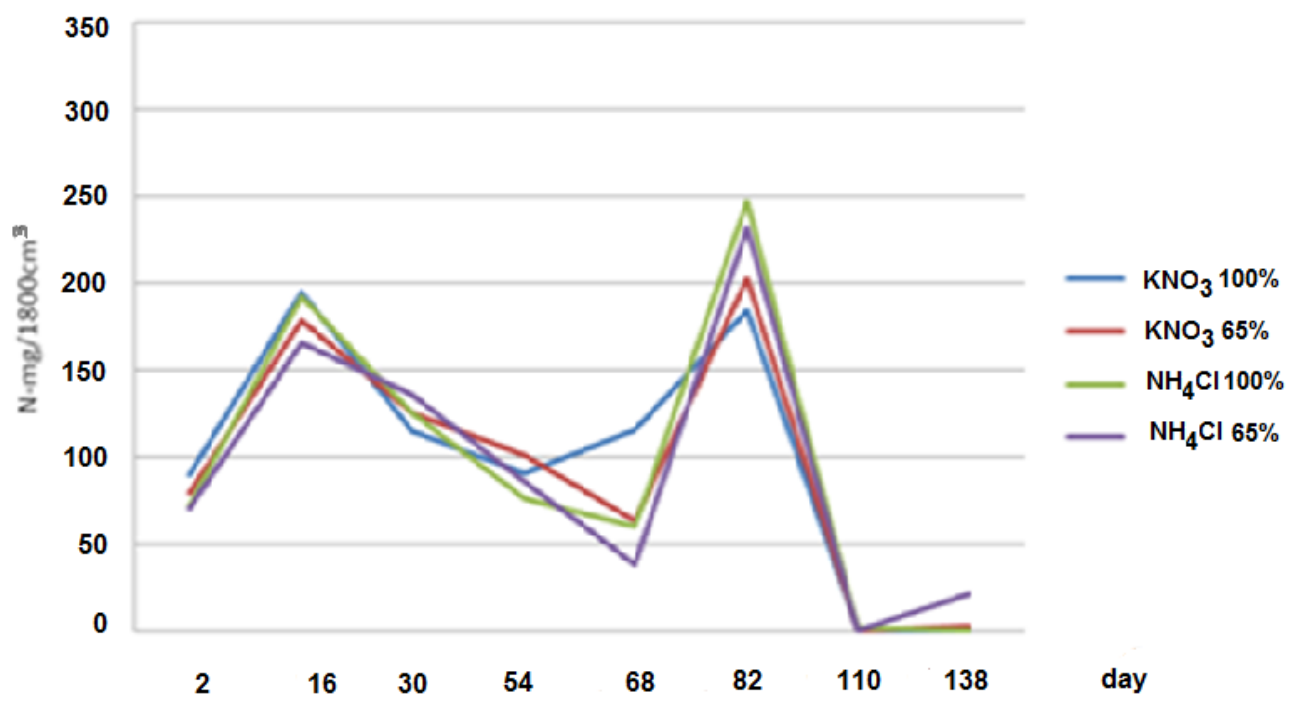

Figure 1. The change of total $N$ gaseous losses increase in the planted pots in the function of sampling time

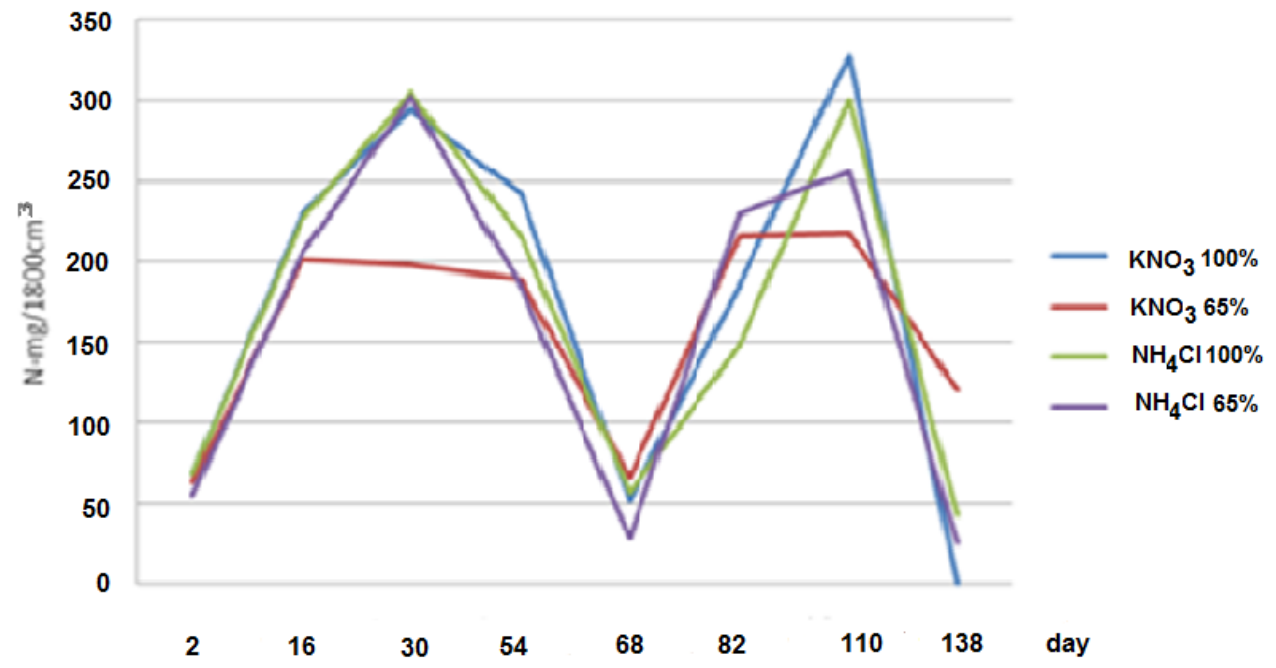

Figure 2. The change of total $N$ gaseous losses increase in the unplanted pots

The change of the relative total $\mathrm{N}$ gaseous losses (Fig.4) was found to be highly influenced by the presence of maize, the fertilizer treatment and soil moisture. It was higher at $\mathrm{KNO}_{3}$ treatment and $100 \%$ WHC soil moisture (except $30^{\text {th }}$ day), than $\mathrm{NH}_{4} \mathrm{Cl}$ treatment and at $65 \%$ WHC. Between the $2^{\text {nd }}$ and $68^{\text {th }}$ day the $100 \%$ WHC increased more intensively the total $\mathrm{N}$ gaseous losses in unplanted pots than with maize compared to $65 \% \mathrm{WHC}$ while $\mathrm{KNO}_{3}$ treatment enhanced the gaseous $\mathrm{N}$ losses stronger in planted pots than without maize compared to $\mathrm{NH}_{4} \mathrm{Cl}$. The forms of the curves are similar among the $2^{\text {nd }}$ and $68^{\text {th }}$ sampling times. The effect of $\mathrm{KNO}_{3}$ and $100 \% \mathrm{WHC}$ is the strongest at 
the start of the experiment $\left(2^{\text {nd }}\right.$ and $16^{\text {th }}$ day) and on the $68^{\text {th }}$ day compare to $\mathrm{NH}_{4} \mathrm{Cl}$ and $65 \% \mathrm{WHC}$.

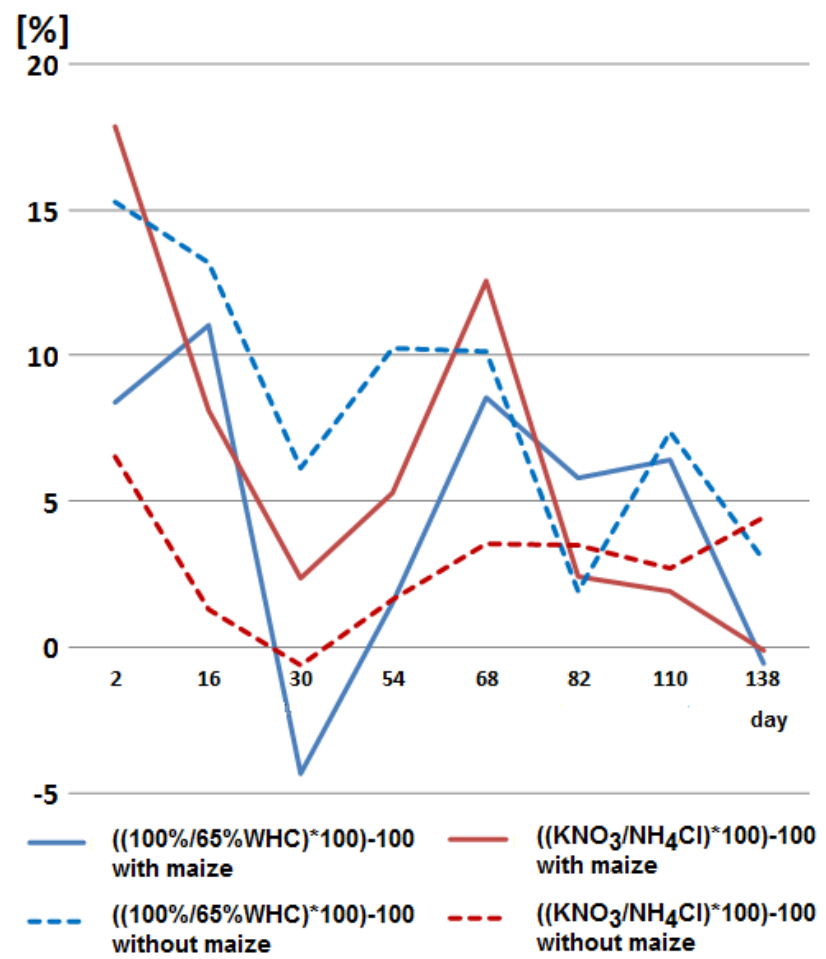

Figure 3. The total $N$ gaseous losses $(+$ planted pots, -unplanted pots) $(L S D 5 \%=41 \mathrm{mgN} / 1800$ $\mathrm{cm} 3$ )

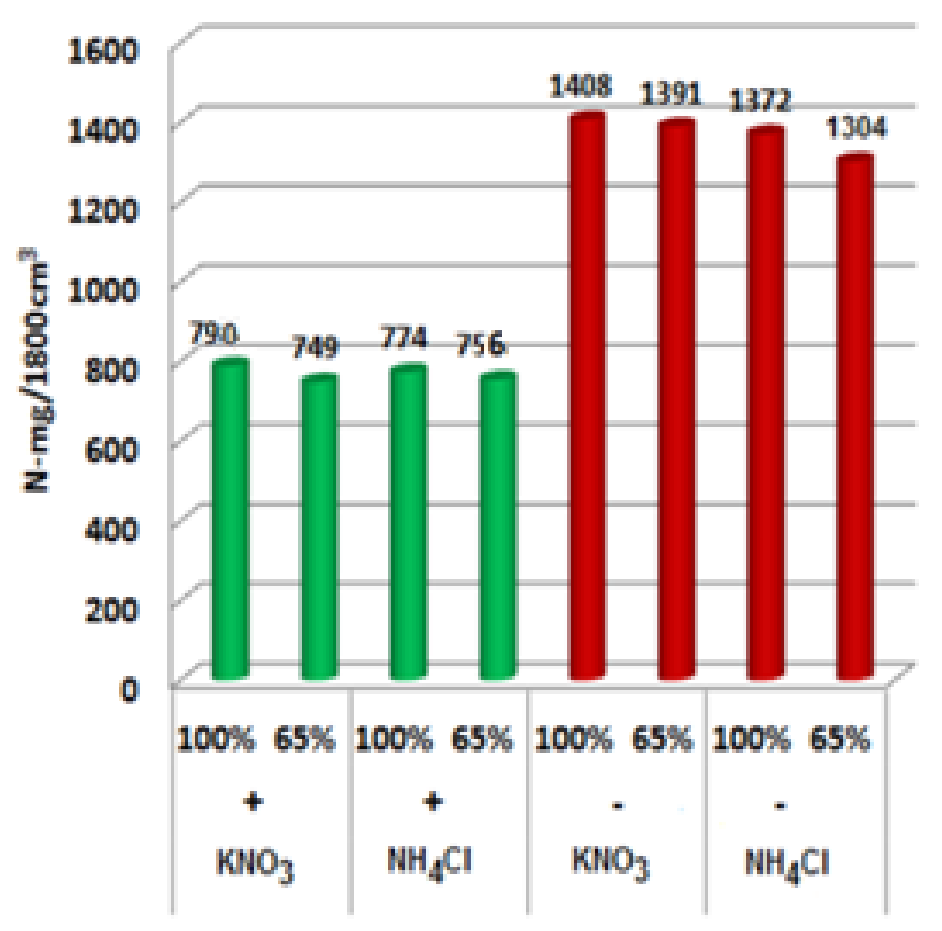

Figure 4. Distribution of the relative total $N$ gaseous losses in the planted and unplanted pots 
The ratio of $\mathrm{NO}_{\mathrm{x}}$ gaseous losses was different in the planted and unplanted pots (Fig.5). In the unplanted pots the ratio of $\mathrm{N}_{2}$ gas was higher (78\%) while the ratios of $\mathrm{N}_{2} \mathrm{O}, \mathrm{NO}_{2}$ and $\mathrm{NO}$ were lower than in planted pots. The $\mathrm{N}_{2}$ and $\mathrm{N}_{2} \mathrm{O}$ gaseous losses were higher by $95 \%$ and by $70 \%$ in the unplanted pots than in the planted pots $\left(\mathrm{N}_{2}\right.$ and $\mathrm{N}_{2} \mathrm{O}: \mathrm{LSD}_{5 \%}=17$ and $5,1 \mathrm{~N}$ and $\mathrm{N}_{2} \mathrm{O} \mathrm{mg} / 1800 \mathrm{~cm}^{3}$ ) (Fig. O).
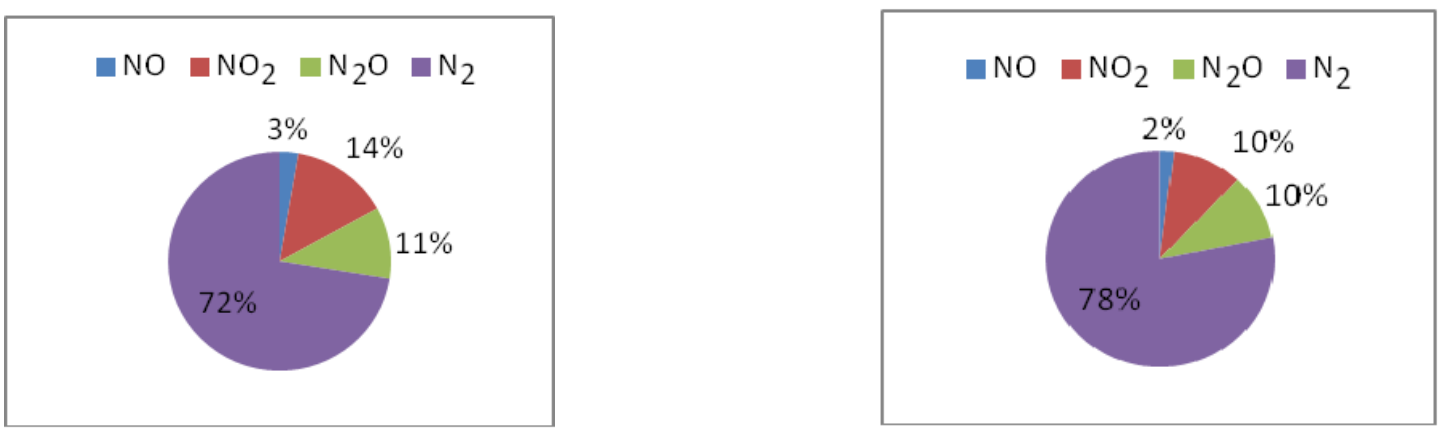

Figure 5. The \% distribution of $N$ gaseous losses in planted (left) and unplanted pots (right)

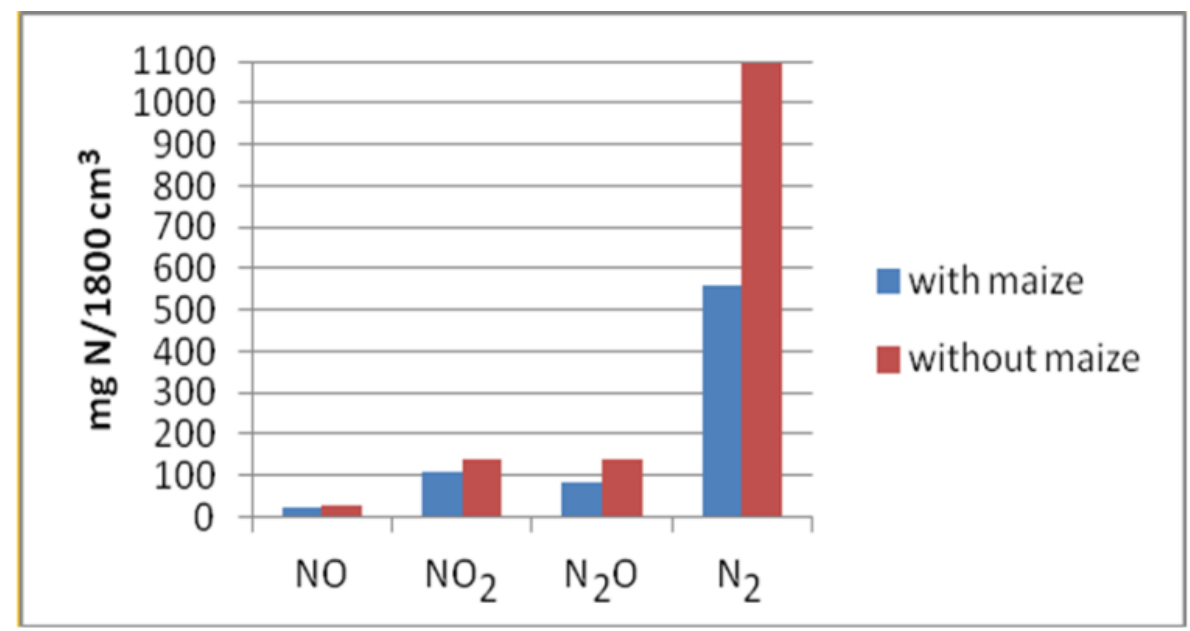

Figure 6. The distribution of $N$ gaseous losses in the planted and unplanted pots

After the $16^{\text {th }}$ day of the experiment the $\mathrm{N}_{2} \mathrm{O}$ gaseous losses were much higher in the unplanted pots than in the planted pots and reached the maximum value $(140 \mathrm{mgN} / 1800$ $\mathrm{cm}^{3}$ ) on the $82^{\text {nd }}$ and $110^{\text {th }}$ day of the experiment depending on treatment (Fig. 7) and soil moisture (Fig.8) while in the planted pots the maximum value (about $80 \mathrm{mgN} / 1800$ $\mathrm{cm}^{3}$ ) was measured on the $82^{\text {nd }}$ day. The $\mathrm{N}_{2} \mathrm{O}$ gaseous losses were significantly higher at $\mathrm{KNO}_{3}$ treatment than $\mathrm{NH}_{4} \mathrm{Cl}$ treatment in the unplanted pots between the $54^{\text {th }}-110^{\text {th }}$ day while in the planted pots between the $2^{\text {nd }}-30^{\text {th }}$ day and on the $82^{\text {nd }}$ day (Fig. 7). It was found that at $\mathrm{WHC}=100 \%$ soil moisture the $\mathrm{N}_{2} \mathrm{O}$ gaseous losses were significantly higher than at $\mathrm{WHC}=65 \%$ in all pots in most of the sampling time (Fig.8). There are two exceptions: in the unplanted pots on the $82^{\text {nd }}$ day when same values were measured at both soil moisture and in the planted pots on the $54^{\text {th }}$ day when the $\mathrm{N}_{2} \mathrm{O}$ gaseous loss was significantly higher at $\mathrm{WHC}=65 \%$ than at $\mathrm{WHC}=100 \%$ soil moisture. 


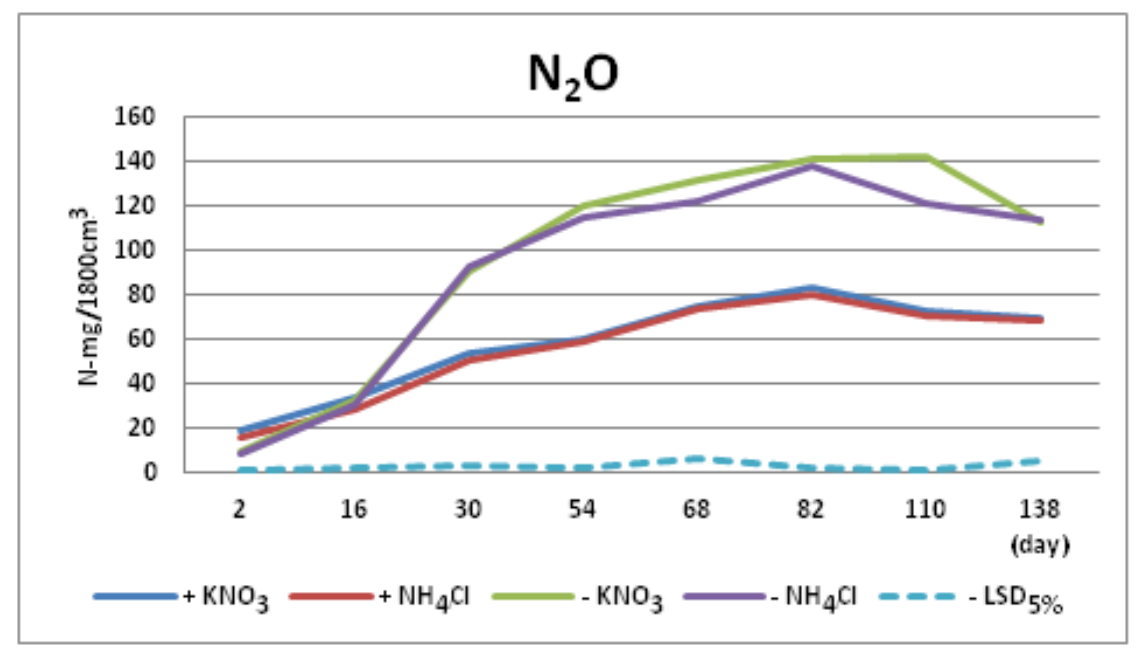

Figure 7. Change of $\mathrm{N} 2 \mathrm{O}$ gaseous losses in the sampling time depend on $\mathrm{N}$ fertilizer forms $(+$ in planted pots, - in unplanted pots)

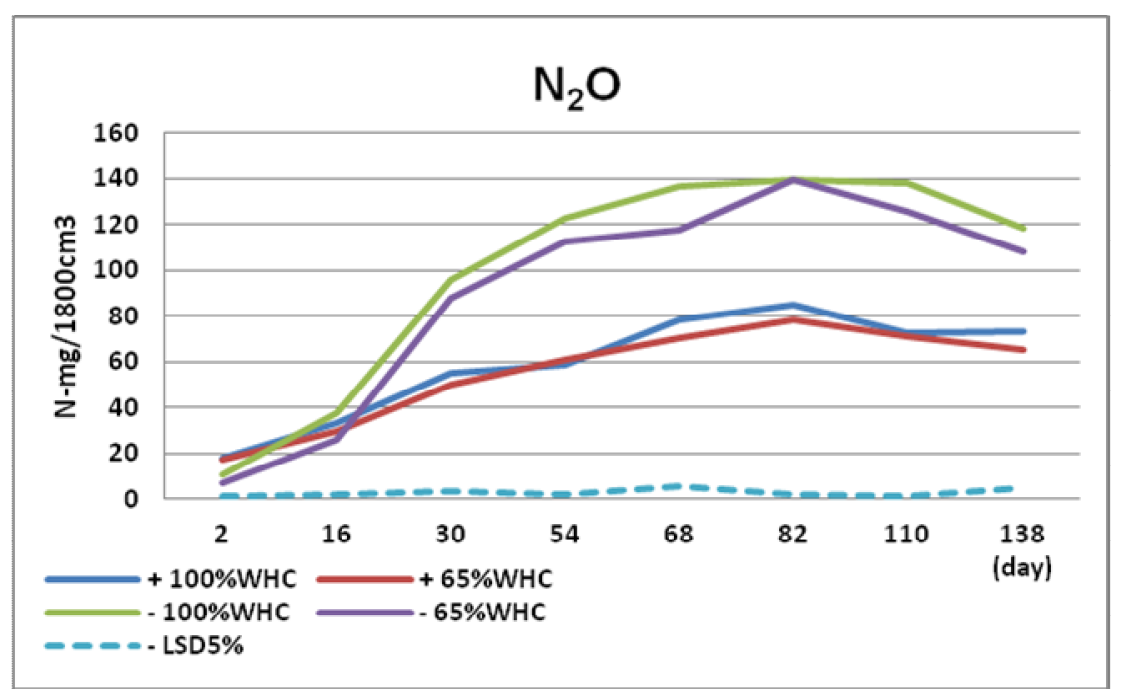

Figure 8. Change of $\mathrm{N} 2 \mathrm{O}$ gaseous losses in the sampling time depend on soil moisture (+in planted pots, - in unplanted pots)

\section{Conclusions}

The total $\mathrm{N}$ and $\mathrm{N}_{2} \mathrm{O}$ gaseous losses were significantly higher in the unplanted pots than in the planted pots in treated samples. In our experiment with maize the total $\mathrm{N}$ gaseous loss was $12-13 \%$ of the applied fertilizer $\mathrm{N}$ while in the pots without maize it was about twice as much $21-22 \%$. Plant $\mathrm{N}$ uptake reduced the $\mathrm{N}$ gaseous losses by about $50 \%$.

In contrast to the treated samples in control samples in the planted pots the total $\mathrm{N}$ and $\mathrm{N}_{2} \mathrm{O}$ gaseous losses were higher than in the unplanted pots due to soil dryingrewetting intensifying microbiological activity, which is more intensive in the rhizosphere around roots (Kuzyakov et al.2000).

The total $\mathrm{N}$ and $\mathrm{N}_{2} \mathrm{O}$ gaseous losses were significantly higher in the $\mathrm{N}$-fertilizer treatments than in control samples due to the increased activity of bacteria, accelerated 
mineralization and release of nutrients by the large fertilizer $\mathrm{N}$ dose (Kuzyakov et al.2000).

The total $\mathrm{N}$ and $\mathrm{N}_{2} \mathrm{O}$ gaseous losses were more intensive in case of $\mathrm{KNO}_{3}$ treatment than in $\mathrm{NH}_{4} \mathrm{Cl}$ treatment in most cases as an assumed consequence of the intensive denitrification.

The total $\mathrm{N}$ and $\mathrm{N}_{2} \mathrm{O}$ gaseous losses were significantly higher at $100 \%$ WHC than $65 \% \mathrm{WHC}$ due to more intensive denitrification processes.

In the unplanted pots the ratio of $\mathrm{N}_{2}$ gas was higher (78\%) than in the planted pots (72\%). The $\mathrm{N}_{2}$ and $\mathrm{N}_{2} \mathrm{O}$ gaseous losses were higher by $95 \%$ and by $70 \%$ in the unplanted pots than in the planted pots due to the absence of plants and more intensive denitrification processes.

It can be concluded that the improperly applied fertilizer causes significant GHG emissions in the absence of plants.

The gaseous $\mathrm{N}$ losses were found to be influenced significantly by the presence or absence of plants, the $\mathrm{N}$ fertilizer form and the soil moisture.

Acknowledgements. The research was supported by Research Centre of Excellence- 175864/2013/TUDPOL and TÁMOP-4.2.2.A-11/1/KONV-2012-0007 projects.

\section{REFERENCES}

[1] Aydinalp, C., Füleky, Gy., Tolner, L. (2010): The comparison study of some selected heavy metals in the irrigated and non-irrigated agricultural soils. Bulgarian Journal of Agricultural Science 16: 754-768.

[2] Blagodatsky S., Smith P. (2012): Soil physics meets soil biology: Towards better mechanistic prediction of greenhouse gas emissions from soil. - Soil Biology and Biochemistry 47: 78-92.

[3] Butterbach-Bahl K, Kock M, Willibald G, Hewett B, Buhagiar S, Papen H, Kiese R. (2004): Temporal variations of fluxes of $\mathrm{NO}, \mathrm{NO}_{2}, \mathrm{~N}_{2} \mathrm{O}, \mathrm{CO}_{2}$ and $\mathrm{CH}_{4}$ in a tropical rain forest ecosystem. - Global Biogeochemical Cycles. 18(3): Article Number GB3012

[4] Cardenas, L., A. Rondon, Johansson C., Sanhueza E. (1993): Effects of soil moisture, temperature, and inorganic nitrogen on nitric oxide emissions from acidic tropival savannah soils. - J. Geophys. Res., 98(14): 783-790.

[5] Chu, H., Hosen, Y., Yagi, K. (2007): $\mathrm{NO}, \mathrm{N}_{2} \mathrm{O}, \mathrm{CH}_{4}$ and $\mathrm{CO}_{2}$ fluxes in winter barley field of Japanse Andisol as affected by $\mathrm{N}$ fertilizer management. - Soil Biology and Biochemistry 39: 330-339

[6] Conrad, R. (1996): Soil microoganisms as controllers of atmospheric trace gases $\left(\mathrm{H}_{2}\right.$, $\mathrm{CH}_{4}, \mathrm{OCS}, \mathrm{N}_{2} \mathrm{O}$, and NO). - Micro-biological Reviews 60: 609-640.

[7] Debreczeni B-né (1995): A nitrogén-mütrágyázás hatása a talajlevegő nitrogéngázösszetételére. - Agrokémia és Talajtan 44(3-4): 299-306.

[8] Debreczeni K., Fischl K., Heltai GY., Bálint Á. (1998): A nitrogén mütrágyázás hatása a talajból származó különböző nitrogéntartalmú gázokra. - Növénytermelés 47(2): 155164.

[9] Delmas, R., Serca, D. Jambert, C. (1997): Global invertory of $\mathrm{NO}_{\mathrm{X}}$ sources. - Nutrient Cycling in Agroecosystems 48: 51-60.

[10] Frolking, S. E., A. R., Moiser, D. S., Ojima, C. Li, W. J., Patron, C. S., Potter, E., Piesack, R., Stenger, C. Haberbosch, P., Dörsch, H., Flessa, K., Smith, A. (1998): Comparison of $\mathrm{N}_{2} \mathrm{O}$ emissions from soils at three temperate agricultural sites: simulations of year-round measurements by four models. - Nutr. Cycl. Agroecosyst. 52: 77-105. 
[11] Gu, C., Maggi, F., Riley, W.J., Hornberger, G. M., Xu, T., Oldenburg, C.M., Spycher, N., Miller, N. L., Venterea, R. T., Steefel, C. (2009): Aqueous and gaseous nitrogen losses induced by fertilizer application. - Journal of Geophysical Research-Biogeosciences 114: Article Number: G01006

[12] Hellebrand, H. J., Kern, J., Scholz, V. (2003): Long-term studies on greenhouse gas fluxes during cultivation of energy crops on sandy soils. - Atmospheric Environment 37:,1635-1644.

[13] Heltai, Gy., Anton, A., Hoffmann, S., Szili-Kovács ,T., Berecz, K., Kampfl, Gy., Kristóf, K., Molnár, E., Horváth, M., Bálint, Á. (2013): Ásványi- és szervestrágyázás hatása a $\mathrm{CO}_{2}$ és $\mathrm{N}_{2} \mathrm{O}$ gázok képződésére a talajban. - Agrokémia és Talajtan 62(1): 143-162.

[14] Jones, S. K., Rees, R. M., Skiba, U. M., Ball, B. C. (2005): Greenhouse gas emissions from a managed grassland. - Global and Planetary Change 47: 201-211.

[15] Kramer, K. J., Moll, H. C., Nonhebel, S. (1999): Total greenhouse gas emissions related to the Dutch crop production system. - Agriculture, Ecosystems and Environment 72: 916.

[16] Kuzyakov, Y., Friedel, J. K., Stahr, K. (2000): Review of mechanisms and quantification of priming effects. - Soil Biology and Biochemistry 32: 1485-1498.

[17] Ma, W. K., Schautz, A., Fishback, L-A. E., Bedard-Haughn, A., Farrell, R. E., Siciliano, S.,D. (2007): Assessing the potential of ammonia oxidizing bavteria to produce nitrous oxide in soils of a high arctic lowland ecosystem on Devon Island, Canada. - Soil Biology and Biochemisty 39: 2001-2013.

[18] Mosier A. R., Duxbury J. M., Freney J. R., Heinemeyer O., Minami K. (1998): Assessing and mitigating $\mathrm{N}_{2} \mathrm{O}$ emissions from agricultural soils. - Climatic Change 40: 7-38.

[19] Nótás, E., Debreczeni, K., Fischl ,K., Heltai, GY. (2003).: Különböző nitrogén mütrágyák és eltérö talajnedvesség szintek hatása a talaj/növény/légkör rendszer N- mérlegére. Növénytermelés 52(6): 667-678.

[20] Pattey, E., Edwards, G. C., Desjardins, R. L., Pennock, D. J., Smith, W., Grant, B., MacPherson, J. I. (2007): Tools for quantifying $\mathrm{N}_{2} \mathrm{O}$ emissions from agroecosystems. Agric. For. Meteorol. 142: 103-119.

[21] Ruser, R., Flessa, H., Russow, R., Schmidt, G., Buegger, F., Munch, J. C.,(2006): Emission of $\mathrm{N}_{2} \mathrm{O}, \mathrm{N}_{2}$ and $\mathrm{CO}_{2}$ from soil fertilized with nitrate: effect of compaction, soil moisture and rewetting. - Soil Biology and Biochemistry 38: 263-274.

[22] Sanhueza, E.,(1992): Biogenic emissions of NO and N2O from tropical savanna soils, in Proceedings of International Symposium on Global Climate Change, pp. 22-34.

[23] Shepard, M. F., Barzetti, S., Hastie, D. R. (1991): The production of $\mathrm{NO}_{\mathrm{x}}$ and $\mathrm{N}_{2} \mathrm{O}$ from a fertilized agricultural soil. - Atmos Environ., 25: 1961-1969.

[24] Stange, F., Döhling, F. (2005): ${ }^{15} \mathrm{~N}$ tracing modell SimKIM to analyse the NO and $\mathrm{N}_{2} \mathrm{O}$ poduction during autotrophic and heterotrophic nitrification in soils. - Isotopes in Environmental and Health Studies. 41(3): 261-274.

[25] Vágó, I., Tolner, L., Eichler-Löbermann, B., Czinkota I., Kovács, B. (2008): Longterm effects of liming on the dry matter production and chemical composition of

perennial ryegrass (Lolium perenne L.). - Cereal Research Communications. 36, 103-106.

[26] Williams, E. J., Guenther, A., Fehsenfeld, F. C. (1992): An inventory of nitric oxide emissions from soils in the United States. - J. Geophys. Res., 97:7511-7519.

[27] Yienger, J. J., Levy, H. (1995): Empirical model of global soil-biogenic $\mathrm{NO}_{\mathrm{x}}$ emission. Journal of Geophysical Research. 100: NO.D6, 11,447-11,464 